\title{
Supplementation with the omega-3 docosahexaenoic acid: influence on the lipid composition and fatty acid profile of human milk
}

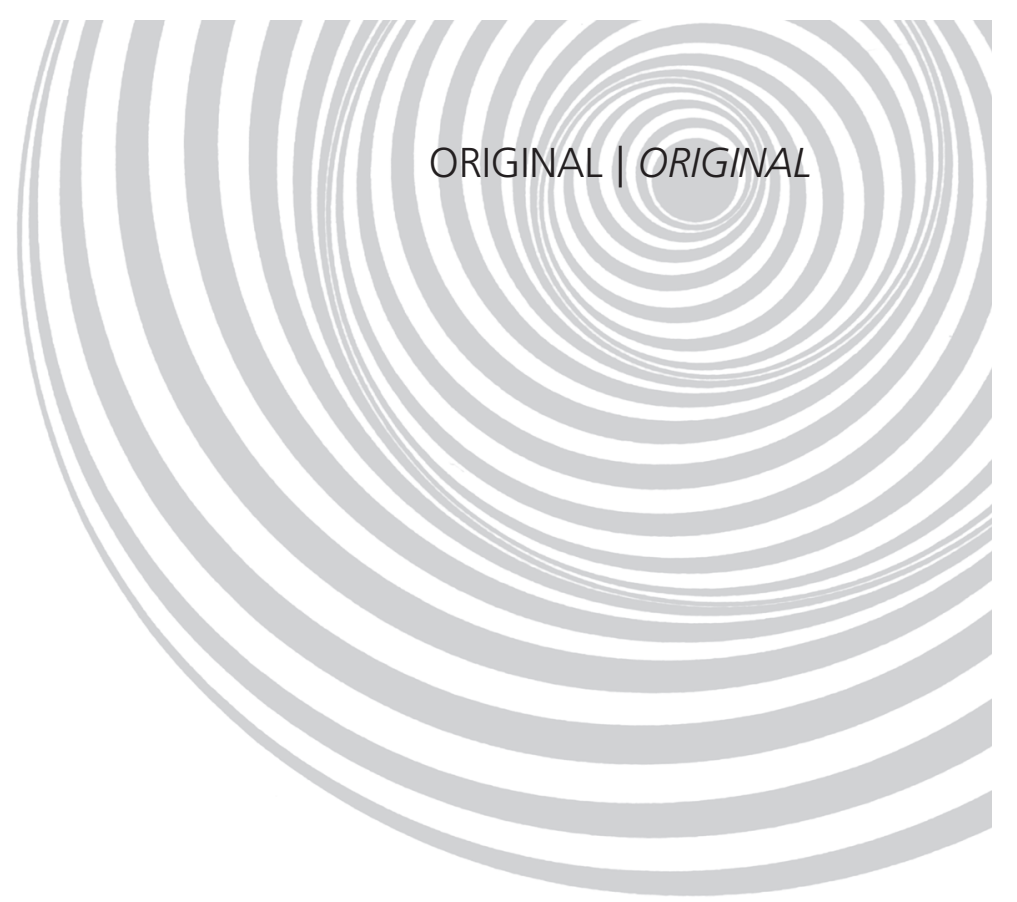

Suplementação com ácido graxo ômega-3

docosahexaenoico: influência sobre a

composição lipídica e perfil de ácidos

graxos no leite humano

Eliana Aparecida Fagundes Queiroz BORTOLOZO'

Elenise SAUER ${ }^{1}$

Marli da Silva SANTOS 1

Sueli Regina BAGGIO²

Guataçara dos SANTOS JUNIOR ${ }^{1}$

Paulo Vitor FARAGO ${ }^{3}$

Lys Mary Bileski CÂNDIDO ${ }^{4}$

Luiz Alberto PILATTI'

A B S T R A C T

\section{Objective}

This study assessed the impact of supplementing the diet of women during pregnancy and lactation with fish oil containing the omega-3 fatty acid docosahexaenoic acid, and its influence on the composition of human milk.

\section{Methods}

The sample comprised 60 women aged 18 to 38 years with appropriate dietary pattern, all of them healthy and nonsmokers. The intervention consisted of a daily supplementation with fish oil capsules that corresponded to a daily intake of $315 \mathrm{mg}$ of docosahexaenoic acid and $80 \mathrm{mg}$ of eicosapentaenoic acid during the third

\footnotetext{
1 Universidade Tecnológica Federal do Paraná. Av. Monteiro Lobato, km 4, Campus Ponta Grossa, 84016-210, Ponta Grossa,

PR, Brasil. Correspondence to/Correspondência para: EAFQ BORTOLOZO. E-mail: <bortolozo@utfpr.edu.br>.

2 Instituto de Tecnologia de Alimentos, Centro de Química de Alimentos e Nutrição Aplicada. Campinas, SP, Brasil.

${ }^{3}$ Universidade Estadual de Ponta Grossa, Centro de Ciências Biológicas e da Saúde, Departamento de Ciências Farmacêuticas.

Ponta Grossa, PR, Brasil

${ }^{4}$ Universidade Tecnológica Federal do Paraná, Setor de Ciências da Saúde, Departamento de Nutrição. Curitiba, PR, Brasil.
} 
28 | EAFQ BORTOLOZO et al.

trimester of pregnancy and the first three months postpartum. The total fat content and fatty acid profile of their milk were determined by creamatocrit and gas chromatography. Descriptive statistics were used for data analysis and the significance level was set at $p<0.05$.

\section{Results}

There was no statistical difference between the fat contents of the study (fish oil capsules) and control (capsules containing corn starch as filler) groups. However, the milk of women taking fish oil contained higher docosahexaenoic and eicosapentaenoic acid levels 30 and 60 days after delivery. These results demonstrate that high omega-3 intake can influence its concentration in human milk.

\section{Conclusions}

Given the importance of docosahexaenoic acid in the neonatal period, it is appropriate for pregnant and breastfeeding women to supplement on long-chain polyunsaturated fatty acids, which may be done by adding fish oil to the regular diet.

Indexing terms: Docosahexaenoic acids. Pregnant women. Lactation. Milk, human. Supplementation feeding.

\section{R E S U M O}

\section{Objetivo}

Este estudo teve como objetivo avaliar o impacto da suplementação na dieta de gestantes e de lactantes com ácidos graxos ômega-3 docosahexaenoico, sob a forma de óleo de peixe, e sua influência na composição do leite humano.

\section{Métodos}

A amostra foi constituída de 60 gestantes, com idade entre 18 e 38 anos, saudáveis, com padrão alimentar adequado e não fumantes. A intervenção consistiu na suplementação da dieta com cápsulas de óleo de peixe, totalizando um consumo diário de $315 \mathrm{mg}$ de ácido docosahexaenoico e $80 \mathrm{mg}$ de ácido eicosapentaenoico, no período entre o terceiro trimestre de gravidez e o terceiro mês após o parto. O teor de lipídeos totais e do perfil de ácidos graxos foi determinado pelos métodos de crematócrito e de cromatografia gasosa. Para a análise dos dados foi utilizada estatística descritiva e nível de significância de $p<0,05$.

\section{Resultados}

Entre o grupo sujeito à dieta suplementada (cápsulas de óleo de peixe) e o grupo controle (cápsulas contendo amido de milho como excipiente), não se constatou diferença estatística quanto aos valores totais de lipídeos. Entretanto, no leite das mães do primeiro grupo, a suplementação com óleo de peixe mostrou teores mais elevados na concentração dos ácidos docosahexaenoico e eicosapentaenoico, nos tempos 30 e 60 dias, demonstrando que um maior consumo de ômega-3 pode influenciar na sua concentração no leite humano.

\section{Conclusão}

Considerando a importância do ácido docosahexaenoico no período neonatal, é adequado incrementar com ácidos graxos poliinsaturados de cadeia longa a alimentação de gestantes e de lactantes, o que pode ocorrer pela suplementação da dieta com óleo de peixe.

Termos de indexação: Ácido docosahexaenóicos. Gestantes. Lactação. Leite humano. Suplementação alimentar.

\section{N TROD UCTIO N}

The Long-Chain Polyunsaturated Fatty Acids (LC-PUFA) of the omega-3 series, such as Docosahexaenoic Acid (DHA), Eicosapentaenoic Acid (EPA) and Arachidonic Acid (AA), are important components of cell membranes and central nervous system cells, and are essential for fetal development and development during the first months of life ${ }^{1-3}$.

The brain develops during the third trimester of pregnancy, when the active formation of neurons begins, and this increases DHA requirement considerably ${ }^{4}$. The amount of DHA that the fetus is capable of synthesizing from its precursors is limited, so it is supplied by the 
placenta, which takes it from the maternal plasma at a rate of $60-70 \mathrm{mg} /$ day and transfers it to the fetal plasma ${ }^{5-7}$.

After birth, polyunsaturated fatty acids are transferred from mother to infant through milk since the infant's liver is immature and still incapable of synthesizing long-chain polyunsaturated fatty acids, which are important for the development of the nervous system ${ }^{6,8}$. Adequate DHA intake has been associated with better cognitive development, growth and visual acuity $^{8-10}$.

During pregnancy, some situations are capable of changing the availability of LC-PUFA, such as inappropriate nutrition, intake of fats and oils having a high omega- 6 to omega- 3 ratio, and multiple and frequent pregnancies, factors that can significantly decrease the body reserves of these acids. The significant demand and accumulation of DHA by the fetus may cause an important reduction in the mother's body reserve of this acid, justifying its supplementation, especially when pregnancies are frequent or multiple ${ }^{11,12}$

After birth, DHA required by the newborn is ensured by the mother's milk which contains a small but significant amount of DHA (0.2-0.6\% of the milk fat) but the amount varies according to the dietary habits of the mother ${ }^{13}$. Maternal DHA intake has a significant impact on its concentration in her plasma and milk $6,8-10,14$. Supplementation with LC-PUFA, especially omega-3, during pregnancy and lactation favors the mental development of the child ${ }^{10,15}$.

Pregnant and lactating women should take $300 \mathrm{mg} /$ day of $\mathrm{DHA}^{16}$. According to Kolelzko et al. ${ }^{17}$, the diet of lactating and pregnant women should provide a minimum of $200 \mathrm{mg} /$ day of DHA. However, it is difficult to establish a precise amount since the mother's ability to store this acid and synthesize it from its precursor may vary ${ }^{15,18}$.

Supplementation of the diet of pregnant women with fish oil (DHA>200mg/day) from the thirtieth week of gestation to delivery increased the amount of omega-3 fatty acids in their milk significantly ${ }^{5}$ Filder et al. ${ }^{19}$ also found a significant increase of DHA in the milk of lactating women whose diets were supplemented with $200 \mathrm{mg} /$ day of DHA. In a study including 98 pregnant women during the last trimester of pregnancy, Dunstan et $a l .^{20}$ found that supplementation with fish oil is an effective way of improving the omega- 3 fatty acid status of newborns. This inference shows the direct correlation between the mother's diet and LC-PUFA concentration in human milk, proving that frequent intake of fish during lactation helps to increase omega-3 fatty acid status 21-23. $^{2}$. However, there is controversy regarding the impact of the mother's diet on lipid profile since individual factors, such as adiposity and nutritional status, may also impact it ${ }^{24}$. In Brazil, there are no longitudinal studies about the theme with the same duration as the present study. In the only existing study, Patin et al. ${ }^{21}$ assessed 31 lactating women who consumed sardines weekly over a period of 30 days.

The objective of the present study was to assess the impact of supplementing the diet of Brazilian pregnant and lactating women living in the state of Paraná with the omega-3 fatty acid DHA in the form of fish oil by verifying its influence on the lipid profile of their milk, especially on DHA content.

\section{METHODS}

The study consisted of a randomized, placebo-controlled trial involving pregnant women who received prenatal care in an obstetric healthcare facility at the municipality of Ponta Grossa, Paraná. The inclusion criteria were: nonsmoker, healthy pregnant women aged 18 to 38 years in the last trimester of pregnancy, no highrisk pregnancy and appropriate dietary patterns. Clinical data were obtained from their medical records. Twenty-four-hour recalls were used for assessing their dietary patterns. They were administered on alternating days during the same week, including a weekend day ${ }^{25,26}$. Food intake 
was reported in preestablished cooking units by the pregnant women during the prenatal visits and by lactating women during home visits. A qualitative analysis was done based on the Food Pyramid Guide. This guide recommends number of portions according to food groups, which are grains (breads, cereals, roots, tubers); vegetables; fruits; meats and milk ${ }^{27}$. During the study period, the recruited women received dietary advice from a dietician once a month.

The intervention period consisted of the last trimester of pregnancy and first three months of lactation, since DHA is an important component of the nervous system and retinal membranes of the fetus, and accumulates mainly during the last months of intrauterine life and first months of life ${ }^{28}$.

The study was done from 2007 to 2008. Its experimental design was approved by the Ethics Committee of the Health Sciences Sector of the Federal University of Paraná, under protocol number 095.SM058/04-07. All participants signed a free and informed consent form before they joined the study.

The casuistic consisted of 80 pregnant women divided into two groups of 40 . The minimum sample size was determined according to Triola ${ }^{29}$. The greatest difficulty regarded estimating the variation (standard deviation) of the data. In order to minimize errors in the mean estimates, the standard deviation was calculated from the results obtained by Patin et al..$^{21}$ and Jensen et al. ${ }^{30}$. The mean standard deviation was considered to be 0.35 and the maximum error margin 0.11 . Considering a significance level of $5 \%$, the study would need a sample size of at least 40 pregnant women.

The 80 participants were randomly divided into two groups of 40 women: the study group who received Omega-3 Supplementation (OG) and the Control Group (CG). The intervention consisted of daily supplementation with five gel capsules of fish oilrich in DHA (Anew Co), totaling $1,150 \mathrm{mg}$ of fish oil, $315 \mathrm{mg}$ of DHA and $80 \mathrm{mg}$ of EPA, according to the recommendation for pregnant and lactating women, which is $300 \mathrm{mg} /$ day of $\mathrm{DHA}^{16}$. The composition of the capsules was confirmed by chromatographic analysis ${ }^{31,32}$. The CG received gel capsules containing cornstarch as filler.

Each milk sample was qualitatively and quantitatively analyzed three times for determining their total fat content and fatty acid profile.The samples were collected as recommended by the Brazilian Pediatric Society (Sociedade Brasileira de Pediatria) 30 (time 30), 60 (time 60) and 90 (time 90) days after delivery. Collection was done at the participants' homes by hand expression. The samples were stored in a sterile recipient, transported in a cooler, frozen and thawed in a water bath at $38^{\circ} \mathrm{C}$ when ready for analysis.

Total fat content was determined by the creamatocrit method adapted for human milk ${ }^{34}$. The omega-3 fatty acids were assessed by gas chromatography ${ }^{32}$ using the gas chromatographer Varian, model 3900. The chromatographic conditions were: programmed column temperature; initial temperature of $120^{\circ} \mathrm{C} / 5 \mathrm{~min}$, heating from $120^{\circ} \mathrm{C}$ to $220^{\circ} \mathrm{C}\left(3^{\circ} \mathrm{C} / \mathrm{min}\right)$ and from $220^{\circ} \mathrm{C}$ to $235^{\circ} \mathrm{C}\left(1^{\circ} \mathrm{C} / \mathrm{min}\right)$, staying at $235^{\circ} \mathrm{C}$ for 12 minutes; the carrier gas was hydrogen at a flow rate of $1 \mathrm{~mL} / \mathrm{min}$; the make-up gas was nitrogen at a flow rate of $30 \mathrm{~mL} / \mathrm{min}$; injector temperature: $270^{\circ} \mathrm{C}$; detector temperature: $300^{\circ} \mathrm{C}$; injection volume: $1 \mu \mathrm{L}$.

For the chromatographic analysis, the samples were prepared by making small changes to the method proposed by Bligh \& Dyer ${ }^{31}$. In the extraction phase, the samples were thawed to about $4^{\circ} \mathrm{C}$ and homogenized. Each $1 \mathrm{~mL}$ aliquot of milk received $10 \mathrm{~mL}$ of methanol, $10 \mathrm{~mL}$ of chloroform and $1.3 \mathrm{~mL}$ of water. The mixture was stirred for 20 minutes followed by extraction, whose filtrate in a vacuum Buchner funnel was transferred to a decanting funnel. The filtrate received $10 \mathrm{~mL}$ of chloroform and $5 \mathrm{~mL}$ of anhydrous sodium sulfate (2\%). After stirring and decantation, the bottom phase was filtered using filter paper with anhydrous sulfate. The sample was dried under nitrogen. For sterification ${ }^{32}, 5 \mathrm{~mL}$ 
of potassium hydroxide in methanol were added to the aliquot, keeping it in a water bath at $70^{\circ} \mathrm{C}$ for 15 minutes. Once cooled, $15 \mathrm{~mL}$ of the esterification reagent were added, and the solution submitted to another water bath at $70^{\circ} \mathrm{C}$ for 10 minutes. After esterification, $10 \mathrm{~mL}$ of hexane and $15 \mathrm{~mL}$ of distilled water were added and stirred. After decantation, a Pasteur pipette was used for collecting the solvent fraction and transferring it to test tubes followed by filtration with anhydrous sulfate. Lastly, $15 \mathrm{~mL}$ of water was added, followed by decantation and collection with a Pasteur pipette. The fatty acids were identified by comparing the retention time of the fatty acids of the samples and standards. A total of 37 saturated, monounsaturated and polyunsaturated fatty acid standards were used (Supelco 37 Component FAME Mix - 47885-U). Fatty acid quantification was done by normalization of the area and the results were expressed in grams per $100 \mathrm{~g}$ of sample.

All data were expressed by descriptive statistics (mean and standard deviation). Next, boxplot diagrams were used for finding possible outliers, which were excluded. Hypothesis testing using analysis of variance was used for verifying the possibility of differences between the means and later, the Tukey test was used for identifying possible significant differences between the means. The significance level for all calculations was set at $5 \%(p<0.05)$. The software Minitab version 15 was used for all the statistical tests.

\section{RE S U LTS}

A group of 60 women completed the study, 25 from the OG and 25 from the CG. These women had a mean age of 25 years and their education level varied from elementary school (34\%; $n=20)$ to high school (37\%, $n=22)$. Most had a mean family in come of two to four minimum wages $(57 \% ; n=34)$. All of them had appropriate dietary patterns for pregnant and lactating women during the entire intervention period (Table 1).
Table 2 shows the lipid profiles of the milk of the two groups. The only significant difference found in DHA content occurred for the intervention group between times OGT30 and OGT90 ( $p=0.026)$. The DHA content of the milk of the control group did not vary during the entire study period $(p=0.939)$. The total fat content of the two groups also did not differ significantly $(p=0.390)$.

Table 3 shows the fatty acid profiles of the groups $O G$ and $C G$ (total percentage of fatty acids) 30, 60 and 90 days after delivery. The DHA and EPA contents (Table 4) of the milk of the mothers in the study group (OG) did not differ significantly during the study period (DHA, $p=0.368 ; \mathrm{EPA}, p=768)$. The DHA and EPA contents of the milk of the mothers in the control group

Table 1. Dietary pattern of the pregnant and lactating women assessed during the last trimester of pregnancy and first three months of lactation. Ponta Grossa (PR), Brazil, 2007-2008.

\begin{tabular}{lccccc}
\hline Group & Milk & Meat & Grains Vegetables & Fruits \\
\hline Recommended $^{*}$ & 3 & 2 & 9 & 4 & 3 \\
$\begin{array}{l}\text { Dietary pattern during } \\
\text { pregnancy }\end{array}$ & 3 & 2 & 9 & 4 & 3 \\
$\begin{array}{l}\text { Dietary pattern during } \\
\text { lactation }\end{array}$ & 3 & 2 & 10 & 4 & 3 \\
\hline
\end{tabular}

${ }^{*}$ Philippi et al. ${ }^{27}$.

Table 2. Mean total lipids* for the study group (OG) and Control Group (CG) on different occasions. Ponta Grossa (PR), Brazil, 2007-2008.

\begin{tabular}{lcc}
\hline Variables & Mean & Standard deviation \\
\hline OGT30 $^{* *}$ & 3.2000 & 0.6121 \\
OGT60 $^{*}$ & 2.7000 & 0.9832 \\
OGT90 $^{* *}$ & 2.2625 & 0.7891 \\
CGT30 & 2.7846 & 0.7519 \\
CGT60 & 2.7364 & 0.5957 \\
CGT90 & 2.7100 & 0.8258 \\
\hline
\end{tabular}

* expressed as $\mathrm{g} \%$ of the total fatty acids.

** significant difference between OGT30 and OGT90.

OGT30, OGT60 and OGT90 - Mean total lipids of the study group 30, 60 and 90 days after delivery, respectively.

CGT30, CGT60 and CGT90 - Mean total lipids of the control group 30 60 and 90 days after delivery, respectively.

OG: Group Who Received Omega-3 Supplementation. 
(CG) also did not differ significantly during the study period(DHA, $p=0.298$; EPA, $p=0.475$ ).

Although the total fat content of the milk of the two groups (OG and $C G$ ) did not differ, the DHA and EPA contents of the milk of the two groups differed significantly $(p<0.001)$. The pairs of means that differed statistically $(p<0.05)$ were: DHAOG30 and DHACG30 (DHA content of the study and control groups 30 days after delivery) and DHAOG60 and DHACG60 (DHA content of the control and study groups 60 days after delivery).

Table 3.Fatty acid profile of the study human milk* (\% of the total fatty acids). Ponta Grossa (PR), Brazil, 2007-2008.

\begin{tabular}{|c|c|c|c|c|c|c|}
\hline \multicolumn{7}{|l|}{ Fatty acids } \\
\hline Days & $30 \mathrm{~d}$ & $60 d$ & $90 \mathrm{~d}$ & $30 \mathrm{~d}$ & $60 \mathrm{~d}$ & $90 \mathrm{~d}$ \\
\hline \multicolumn{7}{|l|}{$C 4: 0$} \\
\hline $\mathrm{C} 6: 0$ & 0.01 & 0.02 & 0.06 & & & \\
\hline C $8: 0$ & 0.14 & 0.20 & 0.13 & 0.12 & 0.11 & 0.12 \\
\hline \multicolumn{7}{|l|}{ C9:0 } \\
\hline C10:0 & 1.40 & 1.62 & 1.47 & 1.24 & 1.22 & 1.26 \\
\hline \multicolumn{7}{|l|}{ C11:0 } \\
\hline C12:0 & 5.28 & 6.09 & 5.67 & 4.87 & 4.69 & 5.24 \\
\hline \multicolumn{7}{|l|}{ C13:0 } \\
\hline C14:0 & 5.16 & 5.30 & 5.35 & 4.69 & 5.11 & 5.67 \\
\hline C14:1 & 0.12 & 0.06 & 0.07 & 0.12 & 0.11 & 0.13 \\
\hline C15:0 & 0.21 & 0.14 & 0.18 & 0.23 & 0.19 & 0.24 \\
\hline \multicolumn{7}{|l|}{ C15:1 } \\
\hline C16:0 & 19.98 & 19.01 & 19.74 & 19.63 & 19.77 & 20.71 \\
\hline C16:1 & 2.40 & 1.90 & 1.82 & 2.17 & 2.21 & 2.29 \\
\hline C17:0 & 0.27 & 0.21 & 0.23 & 0.30 & 0.28 & 0.33 \\
\hline C17:1 & 0.17 & 0.12 & 0.10 & 0.16 & 0.14 & 0.16 \\
\hline C18:0 & 6.43 & 6.33 & 6.81 & 6.63 & 6.39 & 6.39 \\
\hline C18:1/trans & 1.38 & 1.50 & 1.37 & 2.07 & 1.48 & 1.78 \\
\hline C18:1 & 29.59 & 28.64 & 27.21 & 29.90 & 29.32 & 29.64 \\
\hline \multicolumn{7}{|l|}{ C19:0 } \\
\hline C18:2/trans & 0.36 & 0.37 & 0.29 & 0.52 & 0.43 & 0.47 \\
\hline C18:2 & 22.46 & 23.46 & 24.57 & 22.00 & 23.64 & 21.41 \\
\hline$C 20: 0$ & 0.15 & 0.16 & 0.14 & 0.15 & 0.14 & 0.16 \\
\hline C18:3 & 0.12 & 0.17 & 0.17 & 0.17 & 0.15 & 0.19 \\
\hline$C 20: 1$ & 0.29 & 0.30 & 0.19 & 0.35 & 0.26 & 0.32 \\
\hline C18:3/alfa & 1.50 & 1.62 & 1.72 & 1.55 & 1.65 & 1.51 \\
\hline CLA & 0.28 & 0.22 & 0.29 & 0.33 & 0.30 & 0.29 \\
\hline \multicolumn{7}{|l|}{ C21:0 } \\
\hline \multicolumn{7}{|l|}{ C18:4 } \\
\hline C20:2w6 & 0.41 & 0.40 & 0.33 & 0.40 & 0.38 & 0.39 \\
\hline$C 22: 0$ & 0.02 & 0.03 & 0.01 & 0.02 & 0.03 & 0.02 \\
\hline$C 22: 1$ & 0.03 & 0.06 & & 0.06 & 0.17 & \\
\hline$C 20: 3$ & 0.46 & 0.37 & 0.39 & 0.40 & 0.30 & 0.46 \\
\hline$C 20: 3 w 3$ & & 0.07 & & & & 0.02 \\
\hline$C 20: 4$ & 0.48 & 0.41 & 0.38 & 0.49 & 0.48 & 0.44 \\
\hline$C 22: 2$ & 0.03 & 0.03 & 0.01 & 0.02 & 0.02 & 0.04 \\
\hline$C 24: 0$ & 0.02 & 0.04 & 0.01 & 0.02 & 0.04 & 0.04 \\
\hline$C 20: 5$ & & & & 0.01 & & 0.01 \\
\hline \multicolumn{7}{|l|}{ C24:1 } \\
\hline \multicolumn{7}{|l|}{ C22:6w6 } \\
\hline C20:5 (EPA) & 0.08 & 0.08 & 0.05 & 0.11 & 0.09 & 0.11 \\
\hline $\mathrm{C} 22: 6$ (DHA) & 0.10 & 0.08 & 0.03 & 0.33 & 0.32 & 0.21 \\
\hline
\end{tabular}

"OG: Study group consisting of volunteers who received fish oil capsules containing omega-3 fatty acids; CG: Control Group consisting of volunteers who received placebo; EPA: Eicosapentaenoic Acid; DHA: Docosahexaenoic Acid. 
Table 4. DHA and EPA contents ${ }^{*}$ in the milk of the study group (OG) and Control Group (CG) on different occasions. Ponta Grossa (PR), Brazil, 2007-2008.

\begin{tabular}{|c|c|c|c|}
\hline Variables & Mean & $\begin{array}{c}\text { Mean } \\
\text { standard error }\end{array}$ & $\begin{array}{l}\text { Standard } \\
\text { deviation }\end{array}$ \\
\hline$(\mathrm{OG}) \mathrm{C} 22: 6(\mathrm{~T} 30)^{\mathrm{a}}$ & 0.3238 & 0.0365 & 0.1670 \\
\hline$(\mathrm{OG}) \mathrm{C} 22: 6(\mathrm{~T} 60)^{\mathbf{b}}$ & 0.3310 & 0.1200 & 0.4330 \\
\hline (OG)C22:6 (T90) & 0.2071 & 0.0412 & 0.1542 \\
\hline (OG)C20:5 (T30) & 0.1095 & 0.0153 & 0.0700 \\
\hline (OG)C20:5 (T60) & 0.0923 & 0.0178 & 0.0641 \\
\hline (OG)C20:5 (T90) & 0.1071 & 0.0195 & 0.0730 \\
\hline (CG)C22:6 (T30) & 0.1040 & 0.0313 & 0.1567 \\
\hline (CG)C22:6 (T60) & 0.0778 & 0.0222 & 0.0667 \\
\hline (CG)C22:6 (T90) & 0.0300 & 0.0153 & 0.0483 \\
\hline (CG)C20:5 (T30) & 0.0840 & 0.0160 & 0.0800 \\
\hline (CG)C20:5 (T60) & 0.0778 & 0.0147 & 0.0441 \\
\hline (CG)C20:5 (T90) & 0.0500 & 0.0224 & 0.0707 \\
\hline
\end{tabular}

*expressed as \% of the total fatty acids; astatistically different from (CG) C22:6 (DHA); b statistically different from (CG) C22:6.

DHA: Docosahexaenoic Acid; EPA: Eicosapentaenoic Acid; OG: Group Who Received Omega-3 Supplementation.

\section{DISCUSSION}

The participants who remained in the study $(n=60)$ had similar socioeconomic characteristics, and little variation in education level (elementary and high school) and family income (two to four minimum wages). They received nutritional follow-up during the study period and their mean food intake, determined by three dietary recalls, was within the recommendations ${ }^{27}$. Their food intake did not vary significantly throughout the study period.

The mean fat contents at OGT30 were close to those reported by Rona et al. ${ }^{35}$ and Aksit et al. ${ }^{36}$, who studied the fat composition of human milk by creamatocrit. Variation of the total fat content of the milk of the study group OG during the lactating period was similar to those found by other studies ${ }^{36,37}$, showing that fat content decreases over time, possibly because of a reduction in the maternal fat reserves ${ }^{24}$. However, the total fat contents were with in the ranges found in the literature for mature milk ${ }^{38}$.

The same variation was not found in the CG, who presented similar fat contents 30 and
90 days after delivery. Likewise, there was no variation between the two groups on the different occasions, showing that omega-3 supplementation in the proposed dosage did not influence the total fat content of the milk. This result was expected because the supplementation consisted of $1,150 \mathrm{mg}$ of fish oil, and the women had similar dietary patterns.

The fatty acid profile of the two groups presented some variations, but the differences were not uniform. The fat profile found for the CG were similar to those found by Silva et al. ${ }^{39}$, Cunha et al. ${ }^{40}$ and Patin et al. ${ }^{21}$, while studying the fat profile of the milk of Brazilian women, including EPA and DHA. Trans fatty acids were also found by Kolelzko et al. ${ }^{17}$ and by authors of other countries whose results were discussed by Costa \& Sabarense ${ }^{24}$.

Omega-6 (C20:2) fatty acid content of the OG during the entire study period was similar to that found by Silva et al. ${ }^{39}$ and other studies done on human milk in other countries ${ }^{24}$, showing that supplementation with $300 \mathrm{mg} /$ day of omega-3 did not affect the concentration of omega- 6 , despite the fact that these fatty acids compete for the same metabolic pathways ${ }^{11,12,24}$. Short-chain fatty acids (C4:0) were found only in the milk of the control group CG. These fatty acids were not found in human milk by other studies ${ }^{21,39}$ possibly because a high-carbohydrate diet favors the endogenous synthesis of short- and mediumchain fatty acids, while a diet high in polyunsaturated fatty acids results in a higher concentration of the latter in the milk ${ }^{41}$.

Human milk is a natural source of Conjugated Linoleic Acid (CLA) but its concentration was higher 30 and 60 days after delivery in the milk of the study group (OG, $0.30 \%$ and $0.33 \%$ respectively) than in that of the control group. This difference is associated with variation in CLA intake, since humans do not synthesize this fatty acid $^{42}$.

The docosahexaenoic acid and eicosapentaenoic acid contents of the milk of mothers who received supplementation OG were 
also different from those of the mothers who did not receive supplementation CG. The DHA and EPA contents of the study group OG were close to those found by Marangoni et al. ${ }^{43}$, who studied the composition of the milk of Italian women and by Jensen et al. ${ }^{30}$, who also provided fish oil supplementation to their study sample.

The milk of the group that received fish oil supplementation OG had a significantly higher DHA content 30 and 60 days after delivery than the other group CG. This suggests that higher DHA intake may influence its content in human milk, especially during the first weeks after delivery. This result is in agreement with those of other studies that demonstrated the positive influence of omega-3 supplementation on the milk of mothers taking such supplements 1,17,21,28,30. Lauritzen et al..$^{44}$ also observed an increase in the omega-3 content of human milk after fish oil supplementation.

The quality of the fat in the mother's diet may not influence the total fat content of the milk, but influences the fatty acid profile of the milk. This has been observed by the present and other studies ${ }^{21,28}$. The highest DHA requirement occurs during the last trimester of pregnancy and first months of life. Therefore, a high intake of this nutrient by the mother increases its bioavailability to the fetus by placental transport and to the infant by milk $2,17,28$.

The significant impact of DHA intake on the composition of human milk reinforces the recommendation of frequent seafood intake, as recommended by Gaete \& Atalah ${ }^{6}$, or fish oil supplementation ( $300 \mathrm{mg} /$ day of DHA). Jensen ${ }^{28}$ argues that $300 \mathrm{mg} /$ day of DHA may increase the amount of this fatty acid in human milk. It is noteworthy that Brazilian women do not have the habit of consuming fish twice a week, which would help them to meet their $\mathrm{DHA}$ requirement ${ }^{45}$.

\section{CONCLUSION}

The results of the present study showed that supplementation with fish oil providing
$300 \mathrm{mg} /$ day of DHA in women with appropriate dietary patterns increased the amount of this fatty acid in their milk but did not change the total fat content of the milk. Ideally, pregnant and lactating women should keep their DHA status always high, supplementing if necessary.

\section{ACKNOWLEDGMENTS}

We thank the company Anew Co. for donating the fish oil capsules. We thank the city hall of Ponta Grossa for authorizing the study in their healthcare facility. And most of all, we thank the mothers who voluntarily participated in the study.

\section{COLLABORATORS}

EAFQ BORTOLOZO helped to develop the research project and participated in all stages of the study. E SAUER, MS SANTOS and S BAGGIO helped to perform the creamatocrit and chromatographic analyses. G SANTOS JUNIOR planned and performed the statistical analyses. PV FARAGO made the placebo capsules, analyzed the results and helped to write the article. LMB CÂNDIDO helped to plan the study, collect data from the literature, collect milk samples and write the article. LA PILATTI helped to plan the study, analyze the literature data and write the article.

\section{REFER E NCES}

1. Lima MF, Henriques AFD, Santos FD, Andrade PMMA, Carmo MGT. Ácido graxo ômega-3 docosahexaenoico (DHA: C22:6n-3) e desenvolvimento neonatal: aspectos relacionados à sua essencialidade e suplementação. Rev Soc Bras Alim Nutr. 2004; 28:65-77.

2. Silva DRB, Miranda Júnior PF, Soares EA. A importância dos ácidos graxos poli-insaturados de cadeia longa na gestação e lactação. Rev Bras Saúde Mater-Infant. 2007; 7:123-33. doi: 10.1590/\$151 9-38292007000200002.

3. Uauy R, Dangour AD. Nutrition in brain development and aging: role of essential fatty acids. Nutr Rev. 2006; 64(Suppl):24-33. doi:10.1111/j.1753-488 7.2006.tb00242x.

4. Wainwright PE. Dietary essential fatty acids and brain function: a developmental perspective on 
mechanisms. Nutr Society. 2002; 61(1):61-9. doi: 10.1079/PNS2001130.

5. Gaete MG, Atalah ES. Niveles de LC-PUFA n-3 en la leche materna después de incentivar el consumo de alimentos marinos. Rev Chil Pediatr. 2003; 74:158-65.

6. Gaete MG, Atalah ES. Efecto de la suplementación de la dieta de la madre durante la lactancia con ácidos grasos omega-3 en la composición de los lípidos de la leche. Rev Chil Pediatr. 2002; 73(3):239-47. doi: 10.4067/S0370-4106200200 2000300004.

7. Crawford MA. Placental delivery of arachidonic and docosahexaenoic acids: implications for the lipid nutrition of preterm infants. Am J Clin Nutr. 2000; 71(1 Suppl):275s-84s.

8. Araya AJ, Fernándes MP, Rojas GM. Acidos grasos essenciales em eritrocitos de sangre umbilical de recién nacidos prematuros y de término, pequeños 0 adecuados a la edad gestacional. Rev Chil Pediatr. 1998; 69(1):1-7.

9. Innis SM, Elias SL. Intakes of essential n- 6 and n-3 polyunsaturated fatty acids among pregnant Canadian women. Am J Clin Nutr. 2003; 77(2): 473-8.

10. Lauritzen L, Hopope C, Straarup EM, Michaelsen K. Maternal fish oil supplementation in lactation and growth during the first 2,5 years of life. Pediatr Res. 2005; 48:235-42.

11. Valenzuela $A B$, Nieto SK. Ácidos grasos omega- 6 y omega- 3 em la nutrición prinatal: su importância em El desarrolo Del sistema nervioso y visual. Rev Chil Pediatr. 2003; 74(2):197-57. doi: 10.4067/S 0370-41062003000200002.

12. Al MDM, Van Houwelingen AC, Hornstra G. Longchain polyunsaturated fatty acids, pregnancy, and pregnancy outcome. Am J Clin Nutr. 2000; 471 (Suppl):285-91.

13. Koletzko B, Rodríguez-Palmero A, Demmelmair $H$, Fildler N, Jensen R, Sauerwald T. Physiological aspects of human milk lipids. Early Hum Dev. 2001; 65(Suppl):3-18. doi: 10.1016/S0378-3782(01)00 204-3.

14. Henderson RA, Jensen RG, Lammi-Keefe CJ, Ferris AM, Dardick KR. Effect of fish oil on the fatty acid composition of human milk and maternal and infant erythrocytes. Lipids. 1992; 27:863-9. doi: 10.1007/BF02535865.

15. Haggarty P. Effect of placental function on fatty acid requirements during pregnancy. Eur J Clin Nutr. 2004; 58(12):1559-70. doi:10.1038/sj.ejcn.160 2016.

16. Simopoulos AP. Human requirent for $n-3$ polynsaturated fatty acids. Poultry Sci. 2000; 79(7): 961-70. doi:10.1234/12345678.
17. Kolelzko B, Liene E, Agostini C, Campoy C, Celin I, Decsi $T$, et al. The roles of long-chain polyunsaturated fatty acids in pregnancy, lactation and infancy: review of current knowledge and consensus recommendations. J Perinat Med. 2008; 36(1):5-14.

18. Makride M, Neumann M, Jeffrey B, Lien E.L, Gibson $R$. A randomized trial of different ratios of linoleic to $\alpha$-linolenic acid in diet of term infants: effects on visual function and growth. Am J Clin Nutr. 2000; 71(1):120-9.

19. Filder N, Sauerwald T, Pohl A, Demmelmair $H$, Koletzko B. Docosahexaenoic acid transfer into human milk after dietary supplementation: a randomized clinical trial. J Lipid Res. 2000; 41(9): 1376-83.

20. Dustan JA, Mori TA, Barden UM, Beilin LJ, Holt PG, Calder PC, et al. Effects of n-3 polyunsaturated fatty acid supplementation in pregnancy on maternal and fetal erythrocyte fatty acid composition. Eur J Clin Nutr. 2004; 58(3):429-37. doi: 10.1038/sj. ejcn. 1601825.

21. Patin RV, Vitolo MR, Valverde MA, Carvalho PO, Pastore GM, Lopez FA. The influence of sardine consuption on the omega-3 fatty acid content of mature human milk. J Pediatr. 2006; 8(1):63-9. doi: 10.1590/S0021-75572006000100013.

22. Helland IB, Smith L, Saarem K, Saugtad OD, Drevon CA. Similar effects on infants of n-3 and n- 6 fatty acids supplementation to pregnant and lactating women. Pediatrics. 2001; 108(5):E82. doi: 10.15 42/peds.108.5.e82.

23. Scopesi F, Ciangherotti S, Lantieri PB, Risso D, Bertini I, Campone F, et al. Maternal dietary PUFAs intake and human milk content relationships during the first month of lactation. Clin Nutr. 2001; 20(5): 393-97.

24. Costa AGV, Sabarense CM. Modulação e composição ácidos graxos do leite humano. Rev Nutr. 2010; 23(3):445-57. doi: 10.1590/S1415-52732 010000300012.

25. Moreira EAM, Corso ACT, Correia EM, Dorichil SS. Comparação entre duas metodologias de avaliação de consumo alimentar: recordatório de $24 \mathrm{~h}$ e questionário de frequência alimentar. Hig Aliment. 2003; 17(110):24-9.

26. Castro MBT, Anjos LA, Lourenço PM. Padrão dietético e estado nutricional de operários de uma empresa metalúrgica do Rio de Janeiro, Brasil. Cad Saúde Pública. 2004; 20(4):926-34. doi: 10.1590/ S0102-311X2004000400006.

27. Philippi ST, Latterza AR, Cruz AR. Ribeiro LC. Pirâmide alimentar adaptada: guia para escolha de alimentos. Rev Nutr. 1999; 12(1):65-80. doi: 10.1590/ S1415-52731999000100006. 
28. Jensen $C L$. Effects of $n-3$ fatty acids during pregnancy and lactation. Am J Clin Nutr. 2006; 83(Suppl): 1452-7.

29. Triola MF. Introdução à estatística. $7^{a}$ ed. Rio de Janeiro: LTC; 1999.

30. Jensen CL, Maude M, Anderson RE, Heird WC. Effect of docosahexaenoic acid supplementation of lactating women on the fatty acid composition of breast milk and maternal and infant plasma phospholipids. Am J Clin Nutr. 2000; 71(Suppl): 292-9.

31. Bligh EG, Dyer JW. A rapid method of total lipid extraction and purification. Can J Biochem Physiol. 1959; 37(8):901-17.

32. Association Of Official Analytical Chemists. Official methods of analysis. 17nd ed. Gaithersburg: AOCC; 2000.

33. Sociedade Brasileira de Pediatria. Recomendações úteis para a manutenção do aleitamento materno em mães que trabalham fora do lar ou estudam. Conduta do Profissional de Saúde. Rio de Janeiro: SBP; 2003 [acesso 2007 ago 27]. Disponível em: $<$ www.cbpediatria2006.sbp.com.br>.

34. Lucas, A, Gibbs JAH, Lyster RL, Baum JD. Crematocrit: simple clinical technique for estimating fat concentrating and energy value of human milk. Br Med J. 1978; 1(9):1018-20.

35. Rona MS, Novak FR, Portilho M, Pelissari FM, Martins ABT, Matioli G. Efeito do tempo e da temperatura de estocagem nas determinações de acidez, cálcio, proteínas e lipídios de leite humano de doadoras de leite humano. Rev Bras Saúde Mater Infant. 2008; 8(3):257-63. doi: S1519-38 292008000300004

36. Aksit S, Ozkavin N, Caglayan S. Effect of sucking characteristics on breast milk creamatocrit. Paediatr Perinat Epidemiol. 2002; 16(4):355-60.

37. Boersma ER, Offringa PJ, Muskiet FA, Chase WM, Simmons IJ. Vitamin E, lipid fractions, and fatty acid composition of colostrum, transitional milk, and mature milk: in international comparative study. Am J Clin Nutr. 1991; 53(5):1197-204.

38. Macias C, Schweigert FL. Changes in the concentration of carotenoids, vitamina $A$, alpha tocopherol and total lipids human Milk. Ann Nutr Metab. 2001; 45(2):82-5.

39. Silva HLM, Silva MTC, Brandão SCC, Gomes JC, Peternelli LA, Franceschini SCC. Fatty acid composition of mature breast milk in Brazilian women. Food Chem. 2005; 93(2):297-303. doi: S0021-75572005000100012.

40. Cunha J, Costa THM, Ito MK. Influences of maternal dietary intake and suckling on breast mik lipid and fatty acid composition in low-income women from Brasília, Brazil. Early Hum Dev. 2005; 81(3):303-11. doi: 10.1016/j.earlhumdev.2004.08.004.

41. Lawson RE, Moss AR, Givens DI. The role of dairy products in supplying conjugated linoleic acid to man's diet: a review. Nutr Res Reviews. 2001; 14: 153-72. doi: S0954422401000075.

42. Rocquelin G, Tapsoba S, Dop MC, Mbemba F, Traissa CP, Martin-Prével Y. Lipid content and essential fatty acid (EFA) composition of mature Congolese breast milk are influenced by mothers' nutritional status: impact on infants' EFA supply. Eur J Clin Nutr. 1998; 52(3):162-71.

43. Marangoni F, Agostoni C, Lammardo AM, Giovannini M, Galli C, Riva E. Polyunsaturated fatty acid concentrations in human hindmilk are stable throughout 12-month lactation and provide a sustained intake to the infant during exclusive breastfeeding: an Italian study. Br J Nutr. 2000; 84(1):103-9.

44. Lauritzen L, Jorgensen MH, Hansen HS, Michaelsen KF. Fluctuations in human milk long-chain PUFA levels in relation to dietary fish intake 2002. Lipids. 2002; 37(2):237-44. doi: 10.1007/s11745-002-8 86-2.

45. Oliveira T, Marquitti FD, Carvalhaes MABL, Sartoreli DS. Desenvolvimento de um Questionário Quantitativo de Frequencia Alimentar (QQFA) para gestantes usuárias de unidades básicas de saúde de Ribeirão Preto, São Paulo, Brasil. Cad Saúde Pública. 2010; 26(11):2296-306.

Received on: 14/7/2011

Final version on: 19/9/2012

Approved on: 2/10/2012 